\title{
EVA/RAROC vs. MCEV Earnings: A Unification Approach
}

\author{
Christian Kraus \\ Institute of Insurance Science, University of Ulm, Helmholtzstrasse 18, Ulm 89081, Germany \\ Email: christian.kraus@uni-ulm.de
}

This paper compares different performance metrics used for value-based management in life and non-life insurance business. The goal is to find a consistent basis for performance measurement at the insurance group level. This is important since management techniques used in non-life insurance, such as economic value added and risk-adjusted return on capital, are at first sight very different from those used in life insurance, that is, an analysis of market-consistent embedded value earnings, thus making management difficult at the group level. This paper aims to compare and contrast these concepts and to show that all approaches can be unified under a single consistent framework, and that all present residual cash flow concepts that can be linked under the residual income valuation theory. The Geneva Papers (2013) 38, 113 -136. doi:10.1057/gpp.2012.5

Keywords: value-based management; embedded value; franchise value; goodwill

Article submitted 24 May 2011; accepted 9 January 2012; published online 2 May 2012

\section{Introduction}

The insurance industry has several measures to analyse corporate performance, mainly because of the differences between long- and short-term-oriented insurance businesses. While life insurance contracts typically have durations of many years, non-life insurance contracts expire after 1 year and have to be renewed. As a consequence, non-life insurance uses performance metrics such as economic value added (EVA) and risk-adjusted return on capital (RAROC) that focus on the performance of specific periods and thus do not take into account future profits that can be expected from existing business. ${ }^{1}$ Life insurance uses performance measures such as marketconsistent embedded value (MCEV), which are especially appropriate for long-term business, since the valuation is based on the projection of future cash flows. ${ }^{2}$ The performance measure is thereby expressed in terms of change in MCEV over time, the so-called MCEV earnings. ${ }^{3}$

The use of different performance measures, however, may lead to inconsistent management at the group level and therefore preclude integrated performance evaluation and decision-making (for an extended discussion of the significance of this

\footnotetext{
${ }^{1}$ See Diers (2011); Worthington and West (2001).

${ }^{2}$ See Klumpes (2005).

${ }^{3}$ See European Insurance CFO Forum (2009a).
} 
problem we refer to Diers et $a l .^{4}$ ). As a first step to provide a solution for this unfavourable situation, Diers et $a l^{4}$ have transferred the embedded value concept from life to non-life insurance business and present a detailed model of how to determine MCEV in non-life insurance. Furthermore, they use a simplified analysis to demonstrate the use of change in MCEV over time as a performance metric. In contrast, we take into account the value of new business written and extend their simplified illustration to a detailed analysis of MCEV earnings as provided by the European Insurance CFO Forum. ${ }^{3}$ In a detailed theoretical and numerical comparison of the different performance measures (MCEV earnings, EVA and RAROC), we then analyse similarities and differences between the ratios used in life and non-life. The goal is to show that all concepts can be unified under one consistent framework and to emphasise that all represent residual cash flow models that can be linked under the residual income valuation theory. This is important for practitioners, since it shows that all concepts can be used together.

The contribution of this paper is twofold. First, we present a detailed analysis of MCEV earnings for non-life insurance, which is directly comparable to the concept used in life insurance. Second, we provide a detailed comparison between the different concepts used in life and non-life insurance business for measuring value creation. To our knowledge, this is the first attempt to compare the different performance metrics with the overall goal to find a consistent basis for performance measurement at the group level.

The remainder of this paper is organised as follows. The next section describes different metrics used for risk-adjusted performance measurement in non-life insurance. Then a detailed illustration of the analysis of MCEV earnings in life and non-life insurance, taking into account the reconciliation of opening and closing values of MCEV over time, is provided in the subsequent section. The penultimate section gives a theoretical and numerical comparison among EVA, RAROC and MCEV earnings and outlines similarities and differences. The last section concludes.

\section{Value-based management using EVA and RAROC}

Enterprise risk management (ERM), as a holistic approach to integrated risk management, has become an increasingly important topic for academics and practitioners over the last decade. ${ }^{5}$ Especially in the insurance industry, with a unique and complex risk landscape compared to other industries, there is a need for proper risk and capital management. ${ }^{6}$ At the same time, capital provided by the insurance companies' shareholders requires a particular rate of return, named cost of capital, which needs to be measured within the context of performance measurement and reporting. ${ }^{7}$

Identifying the correct cost of capital is one of the central tasks for measuring value in the insurance industry. ${ }^{8}$ In this context, a clear connection between risk

\footnotetext{
${ }^{4}$ See Diers et al. (2009).

${ }^{5}$ See, for example, Dickinson (2001); Hoyt and Liebenberg (2011); Ai et al. (2011); Altuntas et al. (2011).

${ }^{6}$ See Drzik (2005).

${ }^{7}$ See Exley and Smith (2006).
} 
management and value creation is the core of a solid ERM. The connection between risk and value also is highlighted in the definition of the cost of capital. Typically, the cost of capital is given as a risk-free rate (for risk-free investments) plus a risk premium (depending on the risk of the insurer). If the insurer's return is above (below) the cost of capital, value is created (destroyed). Hence, value-based management in the insurance industry is typically based on measures that need to be risk-adjusted and set up in a consistent manner. ${ }^{9}$ In non-life insurance, there are two commonly used concepts for value-based management: EVA and RAROC. ${ }^{10}$

\section{Economic value added (EVA)}

The EVA was developed by the consulting firm Stern Stewart \& Co. It presents an estimate of economic profits to determine the value created by the company. ${ }^{11}$ The methodology is based on a concept called residual income, ${ }^{12}$ which is equal to the annual accounting profit less the required return on capital employed, that is an interest charge on the book value of assets. ${ }^{13}$ As an accounting-based periodic performance measure, residual income has a long history that can be traced back to Marshall $^{14}$ and Solomons. ${ }^{15}$ For a multi-period business valuation process, however, the residual income valuation model only emerged in the 1990s and now is essential in accounting-based valuation. ${ }^{16}$ The EVA is defined as the net operating profit after tax (NOPAT) less the cost of capital employed, which is necessary to produce the NOPAT: ${ }^{11}$

$$
\begin{aligned}
\text { EVA } & =(\text { ROC }- \text { COC }) \cdot \text { Capital Employed } \\
& =\text { NOPAT }- \text { COC } \cdot \text { Capital Employed }
\end{aligned}
$$

The rate of return on capital employed (ROC) is the traditional accountingbased measure of return ( $\mathrm{ROC}=\mathrm{NOPAT} /$ Capital Employed) and $\mathrm{COC}$ is the cost of capital rate applied to the capital that is employed. Value creation thus is

\footnotetext{
${ }^{8}$ See, for example, Hancock et al. (2001); Walhin (2006).

${ }^{9}$ See Liebwein (2006).

${ }^{10}$ See Diers (2011).

${ }^{11}$ See Stewart (1991).

${ }^{12}$ See Worthington and West (2001).

${ }^{13}$ See, for example, Bromwich and Walker (1998); O'Hanlon and Peasnell (1998, 2002).

14 See Marshall (1890).

${ }^{15}$ See Solomons (1965).

${ }^{16}$ See O'Hanlon and Peasnell (2002). The connection between discounted cash flow-based valuation models and accounting-based residual income can be traced back to Preinreich (1937). A first formal link, however, was given in Peasnell (1982). Accordingly, the present value of future cash flows can be written as the sum of current book value and the present value of future profits (see O'Hanlon and Peasnell, 1998). Beyond the residual income valuation model, recently the academic literature has focused on the so-called abnormal earning growth model. For a detailed comparison we refer to Brief (2007).
} 
116

based on the comparison between the productivity and the cost of capital employed.

Beyond the use of EVA as a single-period performance measure, for valuation purposes one also can calculate the so-called market value added (MVA), which is defined as the excess of market value over capital employed:

$$
\text { MVA }=\text { Market Value }- \text { Capital Employed }
$$

According to Stewart ${ }^{11}$ the MVA tells precisely whether or not value for the shareholders has been added. Therefore MVA is equal to the present value of all future EVAs:

$$
\text { MVA }=\sum_{t=1}^{\infty} \frac{\text { EVA }_{t}}{(1+\mathrm{COC})^{t}}=\sum_{t=1}^{\infty} \frac{\text { NOPAT }_{t}-\mathrm{COC} \cdot \text { Capital Employed }_{t-1}}{(1+\mathrm{COC})^{t}}
$$

Thus, in conjunction with MVA, EVA can be used to calculate the market value of the company. The latter is then defined as the sum of projected and discounted future EVAs (i.e. the MVA) and the currently invested capital.

\section{Capital employed and cost of capital rate}

For (non-life) insurance companies, a specific capital structure applies: the insurance premiums typically are received in advance and thus the insurance company has no need for debt financing. ${ }^{17}$ Even among financial institutions, there are significant differences in terms of the structure of liabilities. ${ }^{18}$ Furthermore, for the discounted cash flow-based valuation of financial institutions, the equity approach rather than the entity approach is used, and in this context cash flow to equity is valued directly. ${ }^{19}$ Thus, capital employed, that is invested capital, in the insurance industry is typically composed of equity capital.

Consequently the cost of capital rate can be interpreted as the minimum rate of return on equity capital that is required by the shareholders to make it worthwhile to invest in the company (i.e. the cost of equity capital rate, COE). ${ }^{17}$ For practical applications, the most widely used model to determine the COE is the capital asset pricing model (CAPM). ${ }^{20}$ Accordingly, the COE corresponds to the expected return on firm $i$ given by:

$$
E\left[r_{i}\right]=r_{f}+\beta_{i, m} \cdot\left[r_{m}-r_{f}\right]
$$

where $r_{f}$ equals the expected risk-free rate of return, $r_{m}$ equals the expected market rate of return and $\beta_{i, m}$ corresponds to the systematic (market) risk, defined as the covariance of $r_{i}$ and $r_{m}$ divided by the variance of $r_{i}$. The latter term, the beta coefficient multiplied by the expected market risk premium, corresponds to the risk premium. We therefore can see that the COE is composed of a risk-free rate and a

\footnotetext{
${ }^{17}$ See Danhel and Sosik (2004).

${ }^{18}$ See, for example, Beltratti and Corvino (2008).

${ }^{19}$ See Koller et al. (2005).

${ }^{20}$ See Sharpe (1964); Lintner (1965).
} 
risk premium. According to Cummins and Phillips, ${ }^{21}$ the CAPM is the most widely used asset pricing model, and recent developments such as the Fama-French three-factor model and the full-information beta technique provide generalisations and extensions. In practical applications of the CAPM, the beta coefficient very often comes from regression analysis using historical data.

The cost of capital varies greatly across industries and especially across different lines of business in the insurance industry. It is a very important factor when the EVA concept is applied. Zanjani ${ }^{22}$ presents a model of multi-line pricing and capital allocation for insurance companies and shows the effect of the cost of capital rate on catastrophe insurance markets.

Cummins and Phillips ${ }^{21}$ present different models for estimating the COE capital for property-liability insurers with different business line compositions. Froot ${ }^{23}$ presents a framework for analysing the risk allocation, capital budgeting and capital structure decisions of insurance and reinsurance companies.

Overall, for the purpose of this paper we define the EVA (see Eq. (1)) and the MVA (see Eq. (3)) as follows:

$$
\begin{gathered}
\text { EVA }=\text { NOPAT }- \text { COE } \cdot \text { Equity Capital } \\
\text { MVA }=\sum_{t=1}^{\infty} \frac{\text { NOPAT }_{t}-\mathrm{COE} \cdot \text { Equity Capital }_{t-1}}{(1+\mathrm{COE})^{t}}
\end{gathered}
$$

\section{Risk-adjusted return on capital (RAROC)}

Traditional accounting-based performance measures, such as return on equity (ROE) or return on investment (ROI), evaluate performance without any consideration of risk and uncertainty components. This can lead to misleading indications for relative performance measurement and value creation. ${ }^{24}$ As a consequence, insurance companies have adopted risk-adjusted performance measures, where either the numerator (i.e. the return) or the denominator (i.e. the equity capital) is risk-adjusted, or both the numerator and the denominator are risk-adjusted. According to Goldfarb, ${ }^{24}$ all approaches are referred to as RAROC measures. For the purpose of distinctness, however, we use return over risk-adjusted capital (RORAC) for the first case, risk-adjusted return over capital (RAROC) for the second

\footnotetext{
${ }^{21}$ See Cummins and Phillips (2005).

${ }^{22}$ See Zanjani (2002).

${ }^{23}$ See Froot (2007).

${ }^{24}$ See Goldfarb (2006).
} 
case and risk-adjusted return over risk-adjusted capital for the third case (RARORAC): ${ }^{25}$

$$
\begin{gathered}
\text { RORAC }=\frac{\text { NOPAT }}{\text { Risk-Adjusted Capital }} \\
\text { RAROC }=\frac{\text { NOPAT }- \text { COE } \cdot \text { Equity Capital }}{\text { Equity Capital }}=\frac{\text { EVA }}{\text { Equity Capital }} \\
\text { RARORAC }=\frac{\text { EVA }}{\text { Risk-Adjusted Capital }}
\end{gathered}
$$

Risk-adjusted capital is the amount of capital required to ensure survival in a worst-case scenario. ${ }^{26}$ It often is calculated using quantile-based risk measures such as value at risk (VaR) or expected shortfall (ES). ${ }^{27}$ The big challenge with the use of RAROC measures, however, is finding appropriate capital allocation methods in order to assign the proper amount of capital to a single line of business. ${ }^{28}$ An appropriate model for capital allocation in the insurance industry can be found in Myers and Read. ${ }^{29}$ A critical analysis of this model and an alternative approach can be found in Gründl and Schmeiser. ${ }^{30}$

\section{Discussion}

Within the context of value-based management, different objectives that would lead to a value creation process need to be determined. ${ }^{31}$ Generally, we have to distinguish forwardlooking objectives such as target setting and decision-making from backward-looking objectives such as performance evaluation and compensation schemes. This leads to a natural split between ex ante (evaluation before the performance actually has ocurred) and ex post (evaluation after the performance has taken place) performance metrics.

EVA usually is used ex post for evaluation of the performance over the last reporting period. However, using EVA in conjunction with MVA as a valuation technique clearly links to a forward-looking valuation process. ${ }^{11}$ RAROC concepts, on the other hand, often are used as ex ante concepts where a target rate on return has to be met. In practice, however, they also are used ex post for the evaluation of single portfolios or lines of business, which can be a basis for different compensation schemes. Thus, both $\mathrm{EVA}^{32}$ and $\mathrm{RAROC}^{33}$ are measures of performance that can be used for ex ante and ex post analysis. For the purpose of this paper, however, we only use ex post analysis.

\footnotetext{
${ }^{25}$ See, for example, Nakada et al. (1999); Ward and Lee (2002); Goldfarb (2006).

${ }^{26}$ See Porteous and Tapadar (2008).

${ }^{27}$ See, for example, Dowd and Blake (2006).

${ }^{28}$ See Cummins (2000).

${ }^{29}$ See Myers and Read (2001).

${ }^{30}$ See Gründl and Schmeiser (2007).

${ }^{31}$ See Malmi and Ikäheimo (2003).

${ }^{32}$ See Bromwich and Walker (1998).

${ }^{33}$ See Culp (2000).
} 
EVA vs. RAROC

In order to create shareholder value, the overall goal for the insurance company should be to maximise the different RAROC measures and EVA, that is, the company will create value should the rate of return exceed the COE. The risk-adjusted performance measure then must meet a prescribed minimum target rate of return, called the hurdle rate. ${ }^{34}$ As already mentioned, this is the case if the rate of return (i.e. ROE) exceeds COE. Thus, the hurdle rate is the same as COE and in order to increase shareholder value the following inequalities must hold:

$$
\mathrm{EVA}>0 \Leftrightarrow \mathrm{ROE}>\mathrm{COE} \Leftrightarrow \mathrm{RAROC}>0 \Leftrightarrow \mathrm{RARORAC}>0
$$

The EVA can then be transformed into RAROC and RARORAC using the following equation:

$$
\mathrm{EVA}=\mathrm{RAROC} \cdot \text { Equity Capital }=\text { RARORAC } \cdot \text { Risk-Adjusted Capital }
$$

In the academic literature, especially in the context of capital allocation, it is very common that within the definition of EVA, the amount of risk-adjusted capital (or allocated risk-adjusted capital to one line of business) is set equal to equity capital. ${ }^{35}$ In this context we have the following coherence: ${ }^{28}$

$$
\begin{gathered}
\text { EVA }>0 \Leftrightarrow \text { RORAC }>\text { COE } \\
\text { RORAC }=\frac{\text { NOPAT }}{\text { Risk-Adjusted Capital }}=\frac{\text { EVA }}{\text { Risk-Adjusted Capital }}+\text { COE }
\end{gathered}
$$

In general, however, the risk-adjusted capital and equity capital are different and therefore this coherence cannot be used.

\section{Franchise value}

Within a given accounting framework, the insurance company is able to calculate the corresponding book value of assets, book value of liabilities and hence the book value of equity. For example, if the underlying accounting framework corresponds to local GAAP, then the book value of equity is equal to the difference between the book value of assets and the book value of liabilities, each valued according to local GAAP. If the underlying accounting framework corresponds to an economic approach, then the book value of equity is equal to the difference between the market value of assets and the market value of liabilities, that is the net asset value (NAV). ${ }^{36}$ Generally, however, the market value of equity is higher than the book value of equity; we refer to this difference as franchise value (see Figure 1). ${ }^{37}$

\footnotetext{
${ }^{34}$ See, for example, Guill (1999); Cummins (2000).

${ }^{35}$ See, for example, Cummins (2000); Koller et al. (2005); Gründl and Schmeiser (2007).

${ }^{36}$ See, for example, Hancock et al. (2001); Danhel and Sosik (2004).

${ }^{37}$ See, for example, Sheldon and Smith (2004); Exley and Smith (2006).
} 


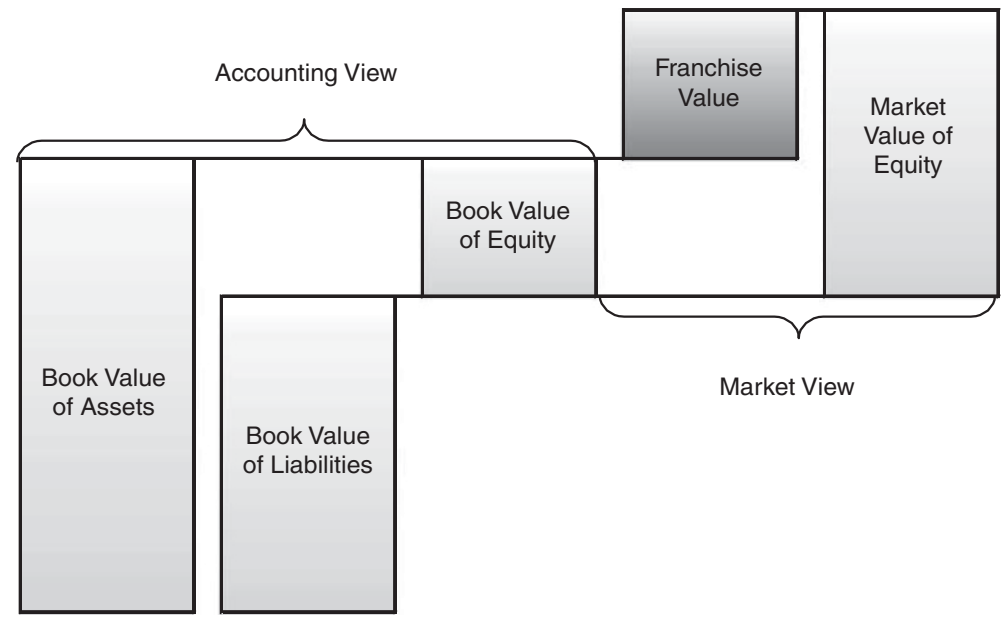

Figure 1. Franchise value.

Exley and Smith $^{7}$ show that the market value of equity, defined as the present value of all future dividends, is the sum of the book value of equity and MVA. Thus, the identity of franchise value and the present value of future EVAs holds true, regardless of the accounting standard chosen. One could argue that the application of a strict economic approach would mean that NAV exactly equals the market value of equity and that the franchise value (or MVA, respectively) would be zero. This, however, is only a theoretical issue and other aspects must be taken into account only by a strict market view and not by traditional accounting-based measures. ${ }^{38}$ For example, future new business usually is not part of any (economic) accounting standard but still contributes to the market value of equity and thus to franchise value. ${ }^{39}$ Sometimes, franchise value also is referred to as the value attributable to the ability to write profitable future new business. ${ }^{40} \mathrm{We}$, however, denote the value of future new business as goodwill, which in our case is part of franchise value.

\section{Accounting bias}

According to De Villiers, ${ }^{41}$ traditional accounting-based measures of return (e.g. the return on capital) fail to assess the market-based measures of return (e.g. total shareholder return) because they are based on historical asset values, which in turn are distorted by inflation and other factors. The discrepancy between accounting-based and market-based measures of return is called "bias in accounting measures of return". ${ }^{7}$ By definition, the EVA presents the difference between the accounting rate of return and the market rate of return that is required by the shareholders. Hence,

\footnotetext{
${ }^{38}$ See, for example, Danhel and Sosik (2004); Sheldon and Smith (2004).

${ }^{39}$ See Sheldon and Smith (2004).

${ }^{40}$ See O'Keeffe et al. (2005).

${ }^{41}$ See De Villiers (1997).
} 


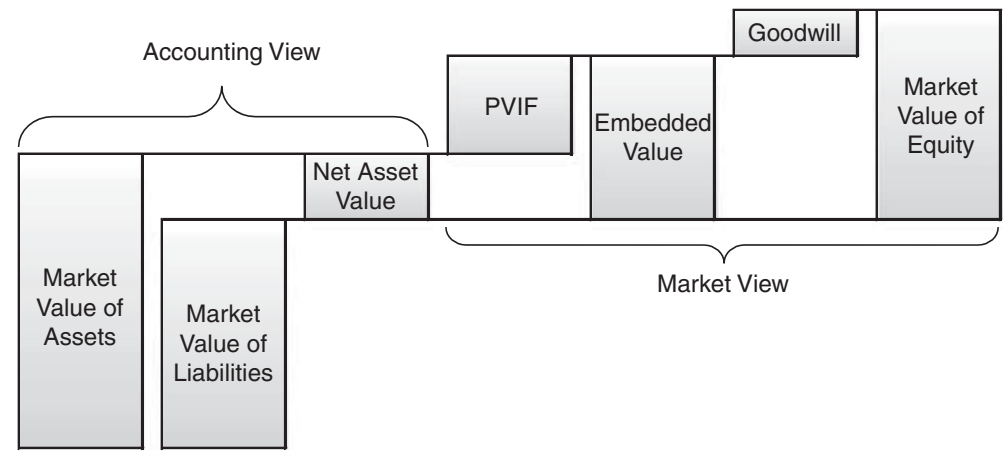

Figure 2. Embedded value.

the MVA, and therefore the franchise value, turns out to be the present value of all future accounting biases. ${ }^{7}$ Brealey et $a l .{ }^{42}$ suggest the use of valuation models, based on discounted cash flows, in order to reduce the accounting bias and to bring accounting-based performance measures more into line with market-based performance measures, as is done by residual income valuation models.

\section{Value-based management using MCEV earnings}

The life insurance industry is increasingly using discounted cash flow-based performance measures such as embedded value. ${ }^{43}$ The embedded value is defined as the sum of NAV and present value of in-force business (PVIF). ${ }^{44}$ The additional consideration of goodwill leads to the so-called appraisal value (see Figure 2). ${ }^{45}$

According to Exley and Smith, ${ }^{7}$ one of the most substantial innovations to minimise accounting bias is the embedded value reporting. The PVIF explains some of the gap between net assets and the market value of equity. This also can be seen as "additional retained profit on an EV basis", which has not been recognised in the books of the insurance company, that is in the calculation of the NAV. ${ }^{46}$ However, in order to eliminate this bias entirely future new business (goodwill) has to be integrated into the valuation model. ${ }^{7}$

For consistent and transparent embedded value reporting, the European Insurance CFO Forum, a discussion group formed by and including the chief financial officers of 20 major European insurance companies, developed the concept of MCEV. ${ }^{3}$ Accordingly, the MCEV consists of the free surplus (FS), the required capital (RC) and the value of in-force business (VIF), which is calculated by the present value of

\footnotetext{
42 See Brealey et al. (2011).

${ }^{43}$ See, for example, Klumpes (2005); Watson Wyatt (2008); KPMG (2009).

${ }^{44}$ See King and McGaughey (2006).

${ }^{45}$ See Frasca and LaSorella (2009).

${ }^{46}$ See Chung-Fern Wu and Wen-Hsin Hsu (2011).
} 
future profits (PVFP) deducted by the time value of financial options and guarantees (TVFOG), the frictional costs of required capital (FCRC) and the cost of residual non-hedgeable risks (CRNHR). The PVFP corresponds to projected profits, that is shareholder cash flows arising from the in-force business after taxation; the TVFOG captures the impact of financial options and guarantees on those cash flows; the FCRC reflect frictional costs for taxation and investment on the assets backing RC; the CRNHR make allowance for the impact of non-hedgeable financial and non-financial risks. For a detailed description of each component, we refer to the European Insurance CFO Forum. ${ }^{3}$

The MCEV of the company corresponds to the value of the business at one specific point in time. For managerial performance evaluation and decision-making, however, we have to analyse the change in MCEV over time. Hence, the actual performance of the company only can be measured by a detailed movement analysis of MCEV earnings, that is, a value-added analysis. The analysis of movement in MCEV provides helpful information for management and can be a good indicator for value creation. ${ }^{47}$ According to Frasca and LaSorella ${ }^{45}$ the goal is to understand why embedded value changes over time.

\section{Analysis of MCEV earnings in life insurance}

By means of a detailed movement analysis template provided by the European Insurance CFO Forum, ${ }^{3}$ the analysis of MCEV earnings is based on the reconciliation of opening $(t=0)$ and closing $(t=1)$ values of MCEV, together with a decomposition of the change in MCEV over time, that is the value added. The value added enables the insurer to identify the value creation or destruction of the in-force business (note, in the case of value destruction, the value added is negative). According to Luk, ${ }^{48}$ however, value added cannot be considered as true value creation for the insurance company; rather, it represents the gross value creation, from which the true profits need to emerge. For this purpose, we utilise the detailed movement analysis template. Accordingly, Figure 3 illustrates the reconciliation of opening and closing values and provides a decomposition of the individual movement components. Movements that are not part of the MCEV earnings should be shown either as opening or as closing adjustments. This include, for example, capital and dividend flows, variances in the foreign exchange rate, and acquired/divested business. ${ }^{49}$ Beyond opening and closing adjustments, four movement items can be identified: (1) new business value, (2) unwinding of MCEV, (3) operating variances, and (4) economic variances.

The (1) new business value corresponds to the value of new business written over the past accounting year and presents a key indicator for analysing the future prospects of the company. The (2) unwinding or rollover of the in-force business corresponds to the expected contribution of existing business to MCEV earnings. The (3) operating variances are divided into non-economic variances affected by (a) experience

\footnotetext{
${ }^{47}$ See, for example, O'Keeffe et al. (2005); Frasca and LaSorella (2009).

${ }^{48}$ See Luk (2004).

${ }^{49}$ See European Insurance CFO Forum (2009b).
} 


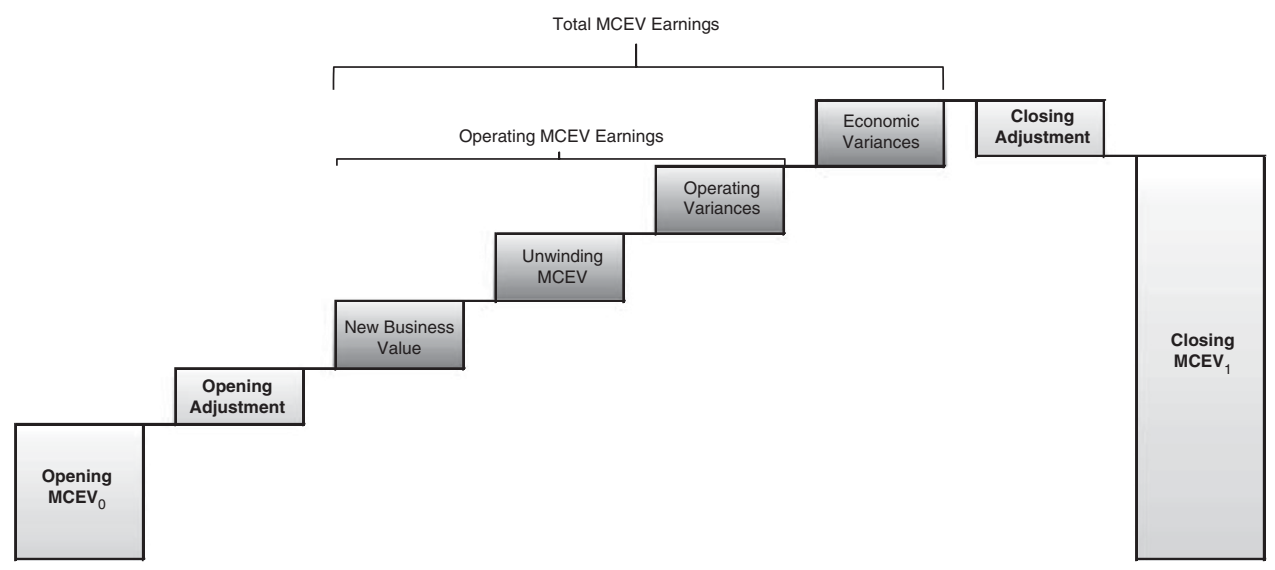

Figure 3. Analysis of MCEV earnings.

variances, that is, changes resulting from the variance between the actual experience and that anticipated, and (b) assumption changes, that is, impacts resulting from the changes in experience assumptions. For the (4) economic variances, there is no need to separate experience variances and assumption changes, since a natural split is not ensured.

O'Keeffe et al. ${ }^{40}$ argue that very often the analysis of movement separates between insurance earnings and investment earnings. The European Insurance CFO Forum ${ }^{3}$ fulfils that by explicitly differentiating between operating MCEV earnings, that is, only taking into account operating variances and total MCEV earnings, that is, the additional consideration of economic variances. Thus, the sum of new business value, unwinding and operating variances, that is, $(1)+(2)+(3)$, corresponds to the so-called operating MCEV earnings. The additional consideration of economic variances (4) leads to the so-called total MCEV earnings. Management can only influence the result on operating MCEV earnings; economic variances are beyond management's control. Furthermore, the unwinding of the insurance business merely equals managements' expectation of the business in the beginning of the year. Thus the true impact for value creation comes from the operating variances and value added by new business. Hence, a detailed movement analysis of MCEV earnings makes it possible to identify the true sources of value creation.

Beside a detailed movement analysis of MCEV earnings, life insurance companies very often disclose information about the percentage return on $\mathrm{MCEV}$, that is, the return over embedded value (ROEV):

$$
\mathrm{ROEV}=\frac{\text { Total MCEV Earnings }}{\text { Opening MCEV }}
$$

Since management does not have any impact on economic variances, it is possible to argue that only the operating MCEV earnings should be used for managerial 
performance evaluation. Thus, alternatively, some companies disclose information about the operating return on MCEV, which is defined as the ratio of the operating MCEV earnings and the (unadjusted) opening MCEV.

\section{Analysis of MCEV earnings in non-life insurance}

We now extend the MCEV valuation model presented in Diers et al. ${ }^{4}$ by a detailed analysis of MCEV earnings for a non-life insurance company that is directly comparable to the concept used in life insurance. Accordingly, the MCEV at $t=0$ can be calculated (in accordance with life MCEV) as the sum of FS, RC and the VIF:

$$
\mathrm{MCEV}_{0}=\mathrm{FS}_{0}+\mathrm{RC}_{0}+\mathrm{VIF}_{0}=\mathrm{NAV}_{0}+\mathrm{VIF}_{0}
$$

The sum of FS and RC corresponds to the NAV and the VIF corresponds to the PVFP deducted by the CRNHR and deducted by FCRC. For life insurance business, the PVFP additionally has to be reduced by the TVFOG. Since we generally do not have (financial) options and guarantees within non-life insurance contracts, this component can be set equal to zero: ${ }^{4}$

$$
\mathrm{VIF}_{0}=\sum_{t=1}^{T}(\underbrace{\frac{\mathrm{NOPAT}_{t}}{\left(1+s r_{t}\right)^{t}}}_{\text {PVFP }}-\underbrace{\frac{\mathrm{COE} \cdot \mathrm{SCR} \mathrm{II}_{t-1}}{\left(1+s r_{t}\right)^{t}}}_{\mathrm{CRNHR}}-\underbrace{\frac{\left(i c r+t r \cdot\left(f r_{t}-i c r\right)\right) \cdot \mathrm{RC}_{t-1}}{\left(1+s r_{t}\right)^{t}}}_{\mathrm{FCRC}})
$$

For the calculation of $\mathrm{VIF}_{0}$, both investment returns, that is, forward rates $\left(f r_{t}\right)$ and discount rates, that is $\left(1 / 1+s r_{t}\right)$, are derived using a risk-free yield curve at $t=0$ given by predefined market spot rates $\left(s r_{t}\right)$. The PVFP is derived by the sum of discounted future net operating profits after tax $\left(\mathrm{NOPAT}_{t}\right)$. The CRNHR are calculated by a cost-of-capital approach similar to the risk-margin approach under Solvency II, ${ }^{50}$ that is, the solvency capital requirements at valuation date $t-1$ (SCR $\mathrm{II}_{t-1}$ ) are multiplied by the COE capital. The FCRC reflects investment costs (icr) and taxation (tr) on assets backing the projected $\mathrm{RC}$ at valuation date $t-1$ $\left(\mathrm{RC}_{t-1}\right)$.

As described in the section "Analysis of MCEV Earnings in Life Insurance", according to the European Insurance CFO Forum, ${ }^{3}$ the change in MCEV over time, that is, the difference between MCEV in $t=1$ and $t=0$, can be expressed by the sum of (1) opening and closing adjustments (Adj), (2) new business value $\left(\mathrm{NBV}_{1}\right)$, (3) unwinding of MCEV $\left(\mathrm{U}_{1}\right)$, (4) operating variances $\left(\mathrm{OpV}_{1}\right)$ and (5) economic variances $\left(\mathrm{EcV}_{1}\right)$. The sum of (1)-(5) corresponds to the value added ( $\left.\triangle \mathrm{MCEV}\right)$,

\footnotetext{
${ }^{50}$ See EIOPA (2010).
} 
whereas the sum of (2)-(5) corresponds to the MCEV earnings:

$$
\Delta \mathrm{MCEV}=\mathrm{MCEV}_{1}-\mathrm{MCEV}_{0}=\mathrm{Adj}+\underbrace{U_{1}+\mathrm{OpV}_{1}+\mathrm{EcV}_{1}+\mathrm{NBV}_{1}}_{\text {MCEV earnings }}
$$

We now give a detailed mathematical description of the four major movement items that can be identified and then present a detailed analysis of MCEV earnings in non-life insurance.

(a) Unwinding $\left(U_{1}\right)$

In order to measure the true value creation of MCEV earnings, the unwinding of in-force business needs to be excluded since there is no additional value creation by the expected (existing) business contribution. For the calculation of the total unwinding effect, we separate between the unwinding effect of the PVFP $\left(U_{1}^{\mathrm{PVFP}}\right)$, the CRNHR $\left(U_{1}^{\mathrm{CRNHR}}\right)$, and the frictional costs of RC $\left(U_{1}^{\mathrm{FCRC}}\right)$. We consider the discount effect, that is, we roll forward the corresponding value by its forward rate $\left(f r_{1}\right)$ and take into account the release of CRNHR and FCRC allowance over the first accounting year. Thus, we have the following coherence:

$$
\begin{gathered}
U_{1}^{\mathrm{PVFP}}=\mathrm{PVFP}_{0} \cdot f r_{1} \\
U_{1}^{\mathrm{CRNHR}}=\mathrm{COE} \cdot \mathrm{SCR} \mathrm{II} I_{0}-\mathrm{CRNHR}_{0} \cdot f r_{1} \\
U_{1}^{\mathrm{FCRC}}=\left(i c r+t r \cdot\left(f r_{1}-i c r\right)\right) \cdot \mathrm{RC}_{0}-\mathrm{FCRC}_{0} \cdot f r_{1}
\end{gathered}
$$

The total unwinding effect of the in-force business $\left(U_{1}\right)$ over the accounting period $t=1$ can be derived by summarising the individual unwinding effects $\left(U_{1}=U_{1}^{\mathrm{PVFP}}+\right.$ $\left.U_{1}^{\mathrm{CRNHR}}+U_{1}^{\mathrm{FCRC}}\right)$. Since $\mathrm{VIF}_{0}=\mathrm{PVFP}_{0}-\mathrm{CRNHR}_{0}-\mathrm{FCRC}_{0}$, overall we obtain:

$$
U_{1}=\mathrm{VIF}_{0} \cdot f r_{1}+\mathrm{COE} \cdot \mathrm{SCR} \mathrm{II}_{0}+\left(i c r+t r \cdot\left(f r_{1}-i c r\right)\right) \cdot \mathrm{RC}_{0}
$$

(b) Operating and Economic Variances ( $O p V_{1}$ and $\left.E c V_{1}\right)$

In order to separate the effect of operating and economic variances from each other, we calculate the MCEV for the accounting period $t=1$ with operating/economic assumptions at $t=1$ denoted by expectations operator $E_{1}^{\mathrm{op}}$ [.] or $\mathrm{E}_{1}^{\mathrm{ec}}$ [.] respectively, and with expected assumptions in $t=0$ denoted by expectations operator $E_{0}[$.$] . This$ difference corresponds to the impact resulting from assumption changes. We also compare the NOPAT (for the accounting period $t=1$ ) based on assumptions in $t=0$ with that based on assumptions at $t=1$. This difference corresponds to the impact of experience variances:

$$
\begin{gathered}
\mathrm{OpV}_{1}=E_{1}^{\mathrm{op}}\left[\mathrm{MCEV}_{1}\right]-E_{0}\left[\mathrm{MCEV}_{1}\right]+\left(E_{1}^{\mathrm{op}}\left[\mathrm{NOPAT}_{1}\right]-E_{0}\left[\mathrm{NOPAT}_{1}\right]\right) \\
E c V_{1}=E_{1}^{\mathrm{ec}}\left[\mathrm{MCEV}_{1}\right]-E_{0}\left[\mathrm{MCEV}_{1}\right]+\left(E_{1}^{\mathrm{ec}}\left[\mathrm{NOPAT}_{1}\right]-E_{0}\left[\mathrm{NOPAT}_{1}\right]\right)
\end{gathered}
$$


(c) New Business Value $\left(\mathrm{NBV}_{1}\right)$

In order to separate the impact of new business value, we first calculate the MCEV at $t=1$ with actual new business value realisations over the accounting period $t=1$ and with operating/economic assumptions at $t=1$ denoted by expectations operator $E_{1}^{\text {all }}[$.]. We then calculate the MCEV at $t=1$ with expected assumptions at $t=0$. In a second step, the difference between the NOPAT with assumptions in $t=1$ and $t=0$ also has to be taken into account (experience variances). In addition, to separate the new business value from the economic and operating variances, those variances also have to be deducted. We thus obtain:

$$
\begin{aligned}
\mathrm{NBV}_{1}= & E_{1}^{\mathrm{all}}\left[\mathrm{MCEV}_{1}\right]-E_{0}\left[\mathrm{MCEV}_{1}\right] \\
& +\left(E_{1}^{\mathrm{all}}\left[\mathrm{NOPAT}_{1}\right]-E_{0}\left[\mathrm{NOPAT}_{1}\right]\right)-\mathrm{OpV}_{1}-\mathrm{EcV}_{1}
\end{aligned}
$$

\section{MCEV earnings vs. residual income valuation}

In its broadest sense, the concept of MCEV earnings is the same as the concept of residual income valuation. Thus, we utilise the expression of O'Hanlon and Peasnell ${ }^{51}$ for "excess money return", which describes the observed excess of the periodic change in entity value over that required by the owners and formulate the net value created $(\mathrm{NVC})$ in terms of MCEV for the accounting period $t=1$ by: ${ }^{52}$

$$
\begin{aligned}
\mathrm{NVC}_{1} & =\underbrace{\left(\mathrm{MCEV}_{1}-\mathrm{MCEV}_{0}+\mathrm{C}_{1}\right)}_{\mathrm{MCEV} \text { earnings }}-\left(k \cdot \mathrm{MCEV}_{0}\right) \\
& =\left(\mathrm{MCEV}_{1}-\mathrm{MCEV}_{0}+C_{1}\right)-\left(U_{1}\right)
\end{aligned}
$$

Hereby $C_{1}$ corresponds to all the cash flows paid out to shareholders, for example, dividends (i.e. opening and closing adjustments); $k$ corresponds to the capital charge based on the assets employed during the accounting period (i.e. the $\mathrm{MCEV}_{0}$ ). ${ }^{51}$ The first term on the right hand side of Eq. (25) corresponds to the MCEV earnings and the second term presents the total unwinding effect of the expected (existing) business contribution in the beginning of the year (see Eq. (21)). ${ }^{53}$ Thus the NVC exactly corresponds to the operating variances, economic variances and new business value (see Eq. (17)).

\footnotetext{
${ }^{51}$ See O'Hanlon and Peasnell (1998).

${ }^{52}$ We adopt the expression "net value created" from Schüler and Krotter (2008).

${ }^{53}$ The latter part of $\mathrm{NVC}_{1}$ corresponds to a situation where expectations in the beginning of the year are met, that is the net value creation is emerged from the gross value creation by deducting the so-called time effect (see Schüler and Krotter, 2008). The time effect based on the (non-life) MCEV valuation model described in Diers et al. (2009) exactly corresponds to the unwinding $U_{1}$. For MCEV calculations in life insurance, however, the time effect would be measured differently; financial options and guarantees imply the use of risk-neutral or deflator valuation techniques (see European Insurance CFO Forum, 2009a) and therefore the expected payoff should be evaluated using stochastic valuation techniques as described in Sheldon and Smith (2004).
} 


\section{Theoretical and numerical comparison of EVA/RAROC and MCEV earnings}

Diers et $a l .{ }^{4}$ transfer the concept of MCEV valuation from life to non-life insurance business in order to find a consistent approach at the insurance group level. In the section "Value-based management using MCEV earnings", we adopt their approach and extend the valuation model by a detailed analysis of MCEV earnings (see the section "Analysis of MCEV earnings in non-life insurance"). On the basis of this performance evaluation model, we now are able to make a theoretical and numerical comparison between EVA/RAROC and MCEV earnings for a non-life insurance company.

\section{Theoretical comparison}

On the basis of the EVA valuation model, the value of the company is defined as the sum of NAV and the MVA. ${ }^{54}$ MCEV is defined as NAV plus VIF. Thus, comparing the EVA valuation model with MCEV requires comparison of MVA with VIF. Table 1 presents a quantitative comparison between the calculations of MVA according to Danhel and Sosik ${ }^{17}$ and of VIF according to Diers et al. ${ }^{4}$ for a non-life insurance company.

For the calculation of MVA, we consider a projection process of discounted future cash flows, that is the present value of all future EVAs. For practical applications, the present value of all future EVAs is divided into the sum of the projection of a forecast period and a terminal value (TV) as perpetuity. The determination of an appropriate time horizon for the EVA valuation process must be a trade-off between the allowance of the long-term character of insurance business on one side and careful consideration of the ability to set correct assumptions for the future on the other side. On average, a projection horizon $T$ of 15-20 years is used before the TV is added as perpetuity. ${ }^{17}$ Taking into consideration the premise of going concern, future cash flows are divided into run-off of existing business and future new business. To determine the COE capital, COE is applied to the NAV at time $t-1$. Finally, the discount rate exactly equals COE. The choice of the cost of capital rate is essential for the determination of MVA, as well as for VIF. For the calculation of an appropriate cost of capital rate for insurance companies we refer to Zanjani, ${ }^{22}$ Cummins and Phillips, ${ }^{21}$ and Froot. ${ }^{23}$

To calculate VIF, however, we have a projection process of discounted future cash flows until the state of complete settlement of the existing insurance business has been reached. In contrast to MVA, VIF does not consider future new business (i.e. goodwill). The projection horizon $T$ therefore emerges from the expectations over the time horizon for the settlement process of existing business. For the determination of the COE capital, COE is applied to the solvency capital requirement according to Solvency II $^{50}$ (SCR II) at time $t-1$. As a discount rate, a risk-free rate, derived from a

\footnotetext{
${ }^{54}$ In an economic framework, such as embedded value, the equity capital is typically composed of the difference between the market value of assets and the market value of liabilities, that is, NAV (see, e.g. Hancock et al., 2001; Danhel and Sosik, 2004). For the purpose of our comparison between EVA/ RAROC and MCEV earnings we thus use NAV for equity capital.
} 
Table 1 Quantitative comparison of MVA and VIF

$$
\begin{aligned}
\mathrm{MVA} & =\sum_{t=1}^{T^{\prime}} \frac{\mathrm{EVA}_{t}}{(1+\mathrm{COE})^{t}}+\mathrm{TV} \\
& =\sum_{t=1}^{T^{\prime}} \frac{\mathrm{NOPAT}_{t}-\mathrm{COE} \cdot \mathrm{NAV}_{t-1}}{(1+\mathrm{COE})^{t}}+\mathrm{TV} \\
& =\sum_{t=1}^{T^{\prime}}\left(\frac{\mathrm{NOPAT}_{t}}{(1+\mathrm{COE})^{t}}-\frac{\mathrm{COE} \cdot \mathrm{NAV}_{t-1}}{(1+\mathrm{COE})^{t}}\right)+\mathrm{TV}
\end{aligned}
$$

$$
\begin{aligned}
\mathrm{VIF}_{0} & =\mathrm{PVFP}_{0}-\mathrm{CRNHR}_{0}-\mathrm{FCRC}_{0} \\
& =\sum_{t=1}^{T}\left(\frac{\mathrm{NOPAT}_{t}}{\left(1+s r_{t}\right)^{t}}\right)-\mathrm{CRNHR}_{0}-\mathrm{FCRC}_{0} \\
& =\sum_{t=1}^{T}\left(\frac{\mathrm{NOPAT}_{t}}{\left(1+s r_{t}\right)^{t}}-\frac{\mathrm{COE} \cdot \mathrm{SCR} \mathrm{II}_{t-1}}{\left(1+s r_{t}\right)^{t}}\right)-\mathrm{FCRC}_{0}
\end{aligned}
$$

Table 2 Qualitative comparison of MVA and VIF

\begin{tabular}{lll}
\hline Criteria & Market value added & Value of in-force business \\
\hline Future new business & Yes & No \\
Time horizon & $\begin{array}{l}\text { Reasonable time horizon } T \text { for cash flow } \\
\text { modelling and additional consideration of } \\
\text { a terminal value }\end{array}$ & $\begin{array}{l}\text { Complete settlement of the } \\
\text { insurance business in year } T\end{array}$ \\
Discount rate & Cost of capital rate & Risk-free rate \\
Frictional costs & No & Yes \\
\hline
\end{tabular}

risk-free yield curve at $t=0$ consisting of spot rates $\left(s r_{t}\right)$ for each relevant time to maturity, is used. Finally, in contrast to MVA, the FCRC are taken into account additionally, which reflect extra costs (taxation and investment on RC) due to regulatory restrictions.

Table 2 presents a qualitative comparison between the principles of calculation of MVA and VIF. A first important difference emerges from the consideration of future new business. While MVA takes into account goodwill (i.e. value of future new business), VIF does not. In addition, while the MVA concept uses a risk-adjusted discount rate $(\mathrm{COE})$ in order to incorporate risk, the VIF makes allowance for risk by the consideration of FCRC and cost of residual non-hedgeable risks (CRNHR) and uses a risk-free discount rate. Due to the new principles for the calculation of MCEV, the concept of a risk discount rate that was used in previous embedded value approaches was replaced by valuing assets and liabilities in line with market prices. $^{55}$

In conclusion, however, the two concepts are not too different. ${ }^{56}$ Through the consideration of future cash flows (and thus the incorporation of franchise value),

\footnotetext{
${ }^{55}$ See De Mey (2009).
} 
EVA valuation and MCEV both reduce the accounting bias and thus bring accounting-based performance measures more in line with market-based performance measures. Both EVA and MCEV valuation can be traced back to the residual income valuation theory. The similarity of the underlying valuation concepts makes it now possible to give a detailed comparison between the performance measures EVA/ RAROC on one side and the MCEV earnings on the other side, and helps us to emphasise existing coherences.

EVA/RAROC vs. MCEV earnings

EVA measures the value added through the accounting profit of one economic period in excess of the capital charge based on the NAV, that is the COE capital. The economic counterpart of EVA, the NVC, is defined as the value added, expressed in terms of change in MCEV over time, in excess of the unwinding effect of existing business contribution (see Eq. (25)). This can also be expressed as: ${ }^{51}$

$$
\mathrm{NVC}_{1}=\mathrm{NAV}_{1}-\mathrm{NAV}_{0}+C_{1}-U_{1}+\left(\mathrm{VIF}_{1}-\mathrm{VIF}_{0}\right)
$$

The difference between $\mathrm{VIF}_{1}$ and $\mathrm{VIF}_{0}$ denotes unrecorded franchise value during the accounting period $t=1$. Hence, we have the following relationship between the EVA and MCEV earnings:

$$
\mathrm{NVC}_{1}=\mathrm{EVA}_{1}+\left(\mathrm{VIF}_{1}-\mathrm{VIF}_{0}\right)-\left(U_{1}-\mathrm{COE} \cdot \mathrm{NAV}_{0}\right)
$$

The NVC can be split into (a) the residual income as excess money return on the book value of equity: $\mathrm{EVA}_{1}$, and (b) the excess money return on unrecorded franchise value: $\left(\mathrm{VIF}_{1}-\mathrm{VIF}_{0}\right)-\left(U_{1}-\mathrm{COE} \cdot \mathrm{NAV}_{t-1}\right){ }^{51}$ Hence, Eq. (27) presents a direct link between the residual income of one accounting period (EVA) and the residual income of all the future accounting periods.

As stated above, RAROC is defined as the ratio of the EVA and NAV. The ROEV is defined as the ratio of the MCEV earnings (over the accounting period $t=1$ ) divided by the opening MCEV (in $t=0$ ) (see Eq. (8)). Hence, using Eq. (27) we have the following coherence between RAROC and ROEV:

$$
\begin{aligned}
\text { ROEV } & =\frac{\text { MCEV earnings }}{\mathrm{MCEV}_{\mathrm{o}}}=\frac{\mathrm{NVC}_{1}+U_{1}}{\mathrm{MCEV}_{\mathrm{o}}} \\
& =\frac{(\mathrm{RAROC}+\mathrm{COE}) \cdot \mathrm{NAV}_{\mathrm{o}}+\left(\mathrm{VIF}_{1}-\mathrm{VIF}_{\mathrm{o}}\right)}{\mathrm{MCEV}_{\mathrm{o}}}
\end{aligned}
$$

The numerator of the ROEV can be split into (a) the return on the book value of equity (i.e. RAROC adjusted by the risk-adjustment factor, COE) and (b) the return on unrecorded franchise value. We thus conclude that the different concepts of EVA/

\footnotetext{
${ }^{56}$ The difference between the EVA valuation model and the MCEV is very similar to the difference between the traditional embedded value concept and the MCEV as described in O'Keeffe et al. (2005). Accordingly the results of both traditional and market-consistent methods should be comparable.
} 
RAROC on one side and MCEV earnings on the other can be unified within a single consistent framework, that is, the residual income valuation theory.

\section{Numerical comparison}

In order to give a numerical comparison between EVA/RAROC and MCEV earnings, we now apply both methods to a fictitious German non-life insurer. All the following numbers and figures are based on numbers and figures used by the Working Group on internal models of the German Actuarial Society. ${ }^{57}$ For simplicity and illustration purposes, we only consider one line of business: motor third-party liability insurance. All MCEV calculations are based on the valuation model described in Diers et al. ${ }^{4}$ and thus all assumptions and parameters are used. For illustration purposes they use two different scenarios for their MCEV calculations: one scenario neglecting renewal business (i.e. cancellation rate of 100 per cent) and another scenario making a reasonable assumption with regard to renewals (using a cancellation rate of 13 per cent). The present analysis is based on the second scenario. The COE is set equal to 6 per cent as suggested by the European Union solvency regulations (Solvency II). ${ }^{50}$ The statutory balance sheet according to German local GAAP at valuation date 31 December 2008 of the considered (fictitious) non-life insurance company is shown in Table 3.

The MCEV valuation model is the basis for setting up an economic balance sheet that considers market values instead of book values and also integrates future cash flows in terms of the present value of future premium income. ${ }^{4}$ The corresponding economic balance sheet states an MCEV in the amount of $129,438 \quad(=34,373+$ $14,828+80,237)$ and is presented in Figure $4 .^{4}$

We now assume that the actual development (actual experience) of the insurance company over the accounting year 2009 shows deviations - with regard to economic and non-economic (operating) factors - from the expectations at the beginning of the year. This leads to economic and operating variances, both based on experience variances and assumption changes. Table 4 sets out the anticipated input

Table 3 Statutory balance sheet as of 31 December 2008

\begin{tabular}{lc}
\hline Assets & Liabilities \\
\hline & Shareholder equity \\
& $€ 48,236$ \\
Book value of assets & Equalisation reserves \\
$€ 236,119$ & $€ 33,932$ \\
& Claim reserves \\
Total $€ 236,119$ & $€ 153,951$ \\
& Total $€ 236,119$ \\
\hline
\end{tabular}

\footnotetext{
${ }^{57}$ See DAV-Arbeitsgruppe Interne Modelle (2008).
} 


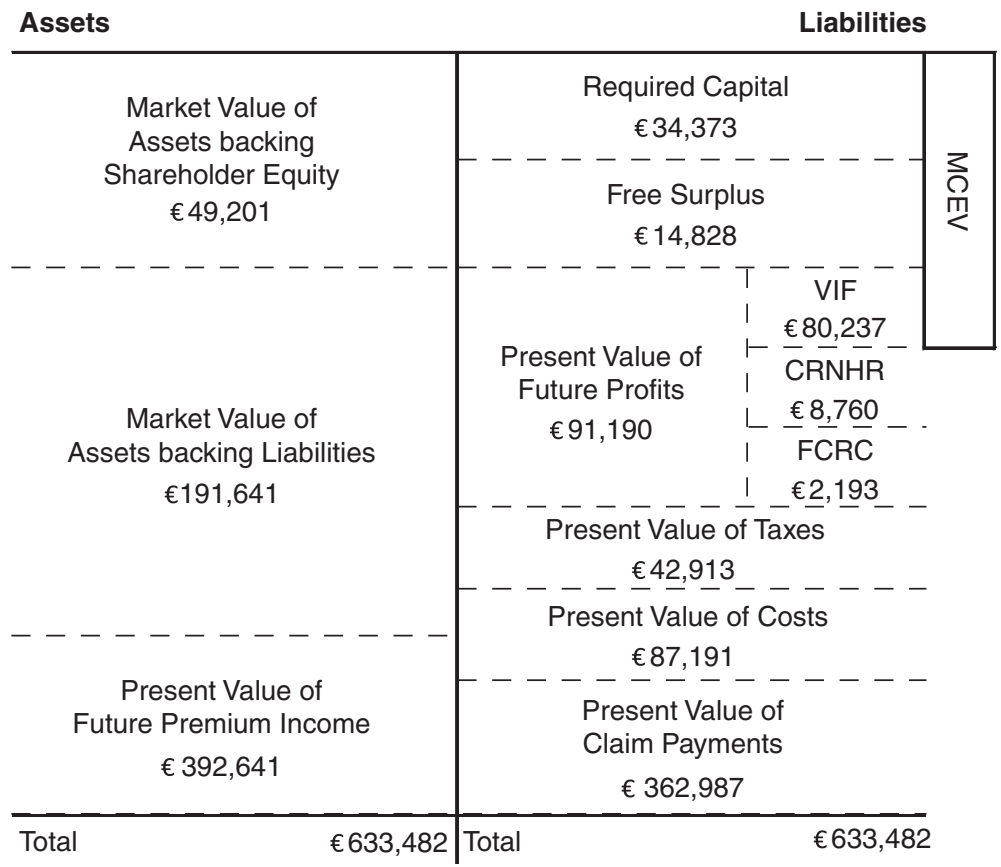

Figure 4. Economic balance sheet as of 31 December 2008.

Table 4 Variance of parameters during accounting year 2009

\begin{tabular}{lrr}
\hline Input factor & Anticipated & Actual \\
\hline Loss ratio (\%) & 70.80 & 70.50 \\
Acquisition costs (\%) & 13.00 & 12.50 \\
Risk-free yield curve (spot rate) (\%) & 3.92 & 3.42 \\
\hline
\end{tabular}

factors and the actual development over the 2009 accounting year. In addition, we assume that 3 per cent of the initial insurance contracts were written as new business during the 2009 accounting year. Overall, the actual performance leads to a statutory balance sheet as well as a profit and loss account (P\&L statement) as presented in Table 5 .

Table 6 presents the associated analysis of MCEV earnings. The opening MCEV is $€ 129,438$ and the closing MCEV is $€ 109,477$. Dividends paid out to the shareholders amount to $€ 28,708(=14,828+13,880){ }^{58}$ Thus, the total MCEV earnings equal $€ 8,747$. These consist of the new business value (€391), the unwinding of the existing

\footnotetext{
${ }^{58}$ Based on Diers et al. (2009), for the reason of simplification, we assume that free surplus (FS) of the accounting year 2008 in the beginning of the accounting year 2009 (opening adjustment) and the annual net income (NOPAT) of the 2009 accounting year at the end of the 2009 accounting year (closing adjustment) are paid as dividends to the shareholders.
} 
Table 5 Statutory balance sheet and profit and loss account as of 31 December 2009

\begin{tabular}{lllr}
\hline Assets & Liabilities & $P \& L$ account & \\
\hline & Shareholder equity & Premium income & $€ 121,530$ \\
& $€ 33,563$ & Claims payment & $€ 87,936$ \\
Book value of assets & Equalisation reserves & Release of claim reserves & $-€ 2,964$ \\
$€ 217,829$ & $€ 33,279$ & Release of Equalisation reserves & $-€ 653$ \\
& Claim reserves & Costs & $€ 23,043$ \\
& $€ 150,987$ & Investment income & $€ 6,243$ \\
Total $€ 217,829$ & Total $€ 217,829$ & Earnings before interest and taxes & $€ 20,412$ \\
& & Taxes & $€ 6,532$ \\
& & NOPAT & $€ 13,880$ \\
\hline
\end{tabular}

Table 6 Analysis of MCEV earnings

\begin{tabular}{lrrrrrr}
\hline & PVFP & FCRC & CRNHR & RC & FS & MCEV \\
\hline Opening MCEV & 91,190 & $-2,193$ & $-8,760$ & 34,373 & 14,828 & 129,438 \\
Opening adjustments & & & & & $-14,828$ & $-14,828$ \\
New business value & 435 & -22 & -22 & 1,118 & $-1,118$ & 391 \\
Unwinding MCEV & 3,575 & 392 & 1,474 & $-4,735$ & 4,735 & 5,441 \\
Operating variances & 3,872 & -124 & -412 & 235 & -235 & 3,336 \\
Operating MCEV earnings & 7,882 & 246 & 1,040 & $-3,383$ & 3,383 & 9,168 \\
Economic variances & -430 & -37 & 46 & 0 & 0 & -421 \\
Total MCEV earnings & 7,452 & 209 & 1,086 & $-3,383$ & 3,383 & 8,747 \\
Closing adjustments & $-13,880$ & & & & $-13,880$ \\
Closing MCEV & 84,762 & $-1,983$ & $-7,674$ & 30,989 & 3,383 & 109,477 \\
\hline
\end{tabular}

insurance business $(€ 5,441)$, operating variances $(€ 3,336)$ and economic variances $(-€ 421)$. More details on the separate presentation between the VIF, RC and FS are available upon request.

To unwind the existing business, two impacts can be identified: (1) we have discount effects since now there is 1 year less of discounting; and (2) we have a release within the FCRC and the CRNHR for risk allowance. ${ }^{59}$ The negative impact of change in interest rates and thus the negative impact of the actual development of financial markets, that is economic variances, are compensated by a positive impact of experience change in the loss ratio and acquisition costs, that is operating variances. Nevertheless, since we have a natural split between operating and experience variances within the movement analysis, the different effects can be identified and explained.

\section{EVA/RAROC vs. MCEV earnings}

Having calculated the MCEV earnings for the accounting year 2009, we can measure the performance of the insurance company for the 2009 reporting period by calculating the NVC. Hereby, the NVC is equal to $€ 3,306(=8,747-5,441)$. The EVA for the accounting year 2009 is equal to $€ 10,928(=13,880-0.06 \cdot 49,201)$. The difference between EVA and $\mathrm{NVC}$ in the amount of $€ 7,622$ exactly corresponds to

\footnotetext{
${ }^{59}$ We refer to Diers et al. (2009) for more details.
} 
the excess money return on unrecorded franchise value, see Eq. $(27)(=(75,105-$ $80,237)-(5,441-0.06 \cdot 49,201))$.

The ROEV is equal to 6.76 per cent $(=8,747 / 129,438)$. The RAROC is equal to 22.21 per cent $(=10,928 / 49,201)$. Furthermore, the ROEV exactly corresponds to the sum of the return on the book value of equity (i.e. RAROC adjusted by COE) and the return on franchise value, see Eq. $(28)=((0.2221+0.06) \cdot 49,201+(75,104-80,237) /) / 129,438$.

Overall we find that the numerical comparison between EVA/RAROC and MCEV earnings leads to the same results as the theoretical comparison within the section "Theoretical comparison" and thus provides a direct link between the different concepts.

\section{Conclusion}

The aim of this paper is to compare the different performance metrics used for valuebased management in life and non-life insurance business in order to identify a consistent basis for performance measurement at the insurance group level. For this purpose, we perform a detailed comparison between the EVA and RAROC concept used in non-life insurance, and the analysis of MCEV earnings used in life insurance.

For a theoretical comparison we oppose EVA valuation and MCEV. We find that, except for some minor details, that is, (1) consideration of goodwill, (2) consideration of frictional cost, and (3) the use of different discount rates, both concepts are very similar and can be traced back to the residual income valuation theory. Furthermore, we show a direct link between EVA/RAROC and MCEV earnings by explaining the difference in terms of unrecorded franchise value. For a numerical comparison, based on the fictitious German non-life insurer described in Diers et al., ${ }^{4}$ we use the movement analysis template provided by the European Insurance CFO Forum ${ }^{3}$ to explain the analysis of MCEV earnings and illustrated the unrecorded franchise value.

Overall, we show that the concept of MCEV earnings and the concept of EVA/ RAROC can be linked under the residual income valuation theory and thus can be used consistently at the insurance group level. Although non-life insurance contracts usually expire after 1 year, they are renewed on a rolling basis and lead to long-term business operations. Hence, at the insurance group level, in line with Exley and Smith ${ }^{7}$ and Brealey et al., ${ }^{42}$ we suggest the use of discounted cash flow-based performance measures such as MVA or MCEV in order to reduce accounting bias and to bring accounting-based measures of return more into line with market-based measures of return.

It is important to note that as a discounted cash-flow-based performance measure the results of the MCEV calculations very much depend on assumptions about interest rates and other future forecasts. ${ }^{60}$ This is exactly the same with the "intrinsic value" concept to evaluate the relative attractiveness of investments, which is already discussed in academia and practice since many years. For example, Warren Buffet suggests using intrinsic value only as internal yardstick instead of an external

${ }^{60}$ The main critical assumptions of MCEV are the choice of a risk-free reference rate, the freedom to choose parameters (e.g. inclusion of a liquidity premium or the choice of a cost of capital rate) and the disregard of the limited liability put option (see Diers et al., 2009). 
reporting measure. ${ }^{61} \mathrm{MCEV}$ should, however, serve both as internal management tool and as an external reporting measure. It is thus absolutely critical to keep in mind the numerous assumptions when evaluating MCEV and its development over time.

\section{References}

Ai, J., Brockett, P.L., Cooper, W.W. and Golden, L.L. (2011) 'Enterprise risk management through strategic allocation of capital', Journal of Risk and Insurance, advance online publication 13 January, doi: 10.1111/ j.1539-6975.2010.01403.x.

Altuntas, M., Berry-Stölzle, T.R. and Hoyt, R.E. (2011) 'Implementation of enterprise risk management: Evidence from the German property-liability insurance industry', The Geneva Papers on Risk and Insurance-Issues and Practice 36(3): 414-439.

Beltratti, A. and Corvino, G. (2008) 'Why are insurance companies different? Limits of convergence among financial institutions', The Geneva Papers on Risk and Insurance - Issues and Practice 33(3): 363-388.

Berkshire Hathaway Inc (1996) Berkshire Hathaway's Owner Manual, Warren E. Buffet.

Brealey, R.A., Myers, S.C. and Allen, F. (2011) Principals of Corporate Finance, New York: McGraw-Hill Irwin.

Brief, R.P. (2007) 'Accounting valuation models: A short primer', Abacus 43(4): 429-437.

Bromwich, M. and Walker, M. (1998) 'Residual income past and future', Management Accounting Research 9(4): 391-419.

Buffet, W.E. (1996) Berkshire Hathaway's Owner Manual, Berkshire Hathaway Inc, http://www.berkshire hathaway.com/owners.html.

Chung-Fern Wu, R. and Wen-Hsin Hsu, A. (2011) 'Value relevance of embedded value and IFRS 4 insurance contracts', The Geneva Papers on Risk and Insurance - Issues and Practice 36(2): 283-303.

Culp, C.L. (2000) 'Ex-ante versus ex-post RAROC', The Journal of Lending \& Credit Risk Management 7(1): $16-25$.

Cummins, D.J. (2000) 'Allocation of capital in the insurance industry', Risk Management and Insurance Review 3(1): 7-28.

Cummins, D.J. and Phillips, R.D. (2005) 'Estimating the cost of equity capital for property-liability insurers', Journal of Risk and Insurance 72(3): 441-478.

Danhel, J. and Sosik, P. (2004) 'Acquisition valuation of P\&C insurance companies', Casualty Actuarial Society Discussion Paper Program, 539-623.

DAV-Arbeitsgruppe Interne Modelle (2008) Interne Risikomodelle in der Schaden-/Unfallversicherung, Karlsruhe: Deutsche Gesellschaft für Versicherungs- und Finanzmathematik, Verlag Versicherungswirtschaft.

De Mey, J. (2009) 'Reporting on the financial performance of life insurers', The Geneva Papers on Risk and Insurance-Issues and Practice 34(2): 228-241.

De Villiers, J. (1997) 'The distortions in economic value added (EVA) caused by inflation', Journal of Economics and Business 49: 285-300.

Dickinson, G. (2001) 'Enterprise risk management: Its origins and conceptual foundation', The Geneva Papers on Risk and Insurance - Issues and Practice 26(3): 360-366.

Diers, D. (2011) 'Management strategies in multi-year enterprise risk management', The Geneva Papers on Risk and Insurance - Issues and Practice 36(1): 107-125.

Diers, D., Eling, M., Kraus, C. and Reuss, A. (2009) Market-Consistent Embedded Value in Non-Life Insurance: How to Measure it and Why, Working Paper, University of Ulm.

Dowd, K. and Blake, D. (2006) 'After VaR: The theory, estimation, and insurance applications of quantilebased risk measures', Journal of Risk and Insurance 72(2): 193-229.

\footnotetext{
${ }^{61}$ See Buffet (1996).
} 
Drzik, J. (2005) 'At the crossroads of change: Risk and capital management in the insurance industry', The Geneva Papers on Risk and Insurance-Issues and Practice 30(1): 72-87.

EIOPA (2010) Committee of the European insurance and occupational pensions authority: EIOPA report on its fifth quantitative impact study (Quis 5) for solvency II, https://eiopa.europa.eu/fileadmin/tx_dam/ files/publications/reports/QIS5_Report_Final.pdf.

European Insurance CFO Forum (2009a) 'Market consistent embedded value principles', http:// www.cfoforum.nl/downloads/MCEV_Principles_and_Guidance_October_2009.pdf.

European Insurance CFO Forum (2009b) 'Market consistent embedded value basis for conclusions', http:// www.cfoforum.nl/downloads/MCEV_Basis_for_Conclusions_October_2009.pdf.

Exley, C.J. and Smith, A.D. (2006) 'The cost of capital for financial firms', British Actuarial Journal 12(1): 229-301.

Frasca, R. and LaSorella, K. (2009) 'Embedded value: Practice and theory, Actuarial Practice Forum, Society of Actuaries, http://www.soa.org/library/journals/actuarial-practice-forum/2009/march/apf-200903-frasca-lasorella.pdf.

Froot, K.A. (2007) 'Risk management, capital budgeting, and capital structure policy for insurers and reinsurers', Journal of Risk and Insurance 74(2): 273-299.

Goldfarb, R. (2006) 'CAS exam 8 study note: Risk-adjusted performance measurement for P\&C insurers', Casualty Actuarial Society, http://www.casact.org/library/studynotes/goldfarb8.2.pdf.

Gründl, H. and Schmeiser, H. (2007) ‘Capital allocation for insurance companies - What good is it?' Journal of Risk and Insurance 74(2): 301-317.

Guill, G.D. (1999) 'Bankers trust and the birth of modern risk management', The Wharton School, Financial Institutions Center, circa, 1999, pp. 1-23.

Hancock, J., Huber, P. and Koch, P. (2001) 'Value creation in the insurance industry', Risk Management and Insurance Review 4(2): 1-9.

Hoyt, R.E. and Liebenberg, A.P. (2011) 'The value of enterprise risk management', Journal of Risk and Insurance 38(4): 795-822.

King, D. and McGaughey, K. (2006) 'Capital allocation and performance measurement: A case study', working paper presented at the International Congress of Actuaries 2006, Paris.

Klumpes, P.J.M. (2005) 'Managerial use of discounted cash-flow or accounting performance measures: Evidence from the U.K. life insurance industry', The Geneva Papers on Risk and Insurance-Issues and Practice 30(1): 171-186.

Koller, T., Goedhart, M. and Wessels, D. (2005) Valuation: Measuring and Managing the Value of Companies, New Jersey: McKinsey \& Company, John Wiley \& Sons.

KPMG (2009) 'The future of financial performance measurement', KPMG Insurance Advisory, White Paper.

Liebwein, P. (2006) 'Risk models for capital adequacy: Applications in the context of solvency II and beyond', The Geneva Papers on Risk and Insurance - Issues and Practice 31(3): 528-550.

Lintner, J. (1965) 'The valuation of risk assets and the selection of risky investments in stock portfolios and capital budgets', Review of Economics and Statistics 47: 13-37.

Luk, P. (2004) 'Measuring true profits using embedded value', Plan-B Consulting Ltd., May 2004.

Malmi, T. and Ikäheimo, S. (2003) 'Value based management practices - Some evidence from the field', Management Accounting Research 14(3): 235-254.

Marshall, A. (1890) Principles of Economics, London: Macmillan Press Ltd.

Myers, S.C. and Read, J.A. (2001) 'Capital allocation for insurance companies', Journal of Risk and Insurance 68(4): 545-580.

Nakada, P., Shah, H., Koyluoglu, H.U. and Colignon, O. (1999) 'RAROC: A catalyst for improved capital management in the property and casualty insurance industry', Journal of Risk Finance 1(1): $1-18$.

O'Hanlon, J. and Peasnell, K. (1998) 'Wall Street's contribution to management accounting: The Stern Stewart EVA financial management system', Management Accounting Research 9: 421-444.

O'Hanlon, J. and Peasnell, K. (2002) 'Residual income and value creation: The missing link', Review of Accounting Studies 7(2-3): 229-245.

O'Keeffe, P.J.L., Desai, A.J., Foroughi, G.J., Hibbett, G.J., Maxwell, A.F., Sharp, A.C., Taverner, N.H., Ward, M.B. and Willis, F.J.P. (2005) 'Currents developments in embedded value reporting', British Actuarial Journal 11(III): 407-496. 
136

Peasnell, K.V. (1982) 'Some formal connections between economic values and yields and accounting numbers', Journal of Business Finance \& Accounting 9(3): 361-381.

Porteous, B. and Tapadar, P. (2008) 'The impact of capital structure on economic capital and risk adjusted performance', Astin Bulletin 38(1): 341-380.

Preinreich, G.A.D. (1937) 'Valuation and amortization', The Accounting Review 12(3): 209-226.

Schüler, A. and Krotter, S. (2008) 'The link between residual income and value created for levered firms: A note', Management Accounting Research 19: 270-277.

Sharpe, W.F. (1964) 'Capital asset prices: A theory of market equilibrium under conditions of risk', Journal of Finance 19(3): 425-442.

Sheldon, T.J. and Smith, A.D. (2004) 'Market consistent valuation of life assurance business', British Actuarial Journal 10(3): 543-626.

Solomons, D. (1965) Divisional Performance Measurement and Control, Homewood, IL: Richard D. Irwin. Stewart III, G.B. (1991) The Quest for Value, New York: Harper-Collins.

Walhin, J-F. (2006) 'Value creation for insurers', Blätter der DGVFM 27(4): 681-693.

Ward, L.S. and Lee, D.R. (2002) 'Practical application of the risk-adjusted return on capital framework', Casualty Actuarial Society Forum, Summer 2002.

Watson Wyatt (2008) 'MCEV principles: The industry view', Survey of the European Market, September 2008.

Worthington, A.C. and West, T. (2001) 'Economic value-added: A review of the theoretical and empirical literature', Asian Review of Accounting 9(1): 67-86.

Zanjani, G. (2002) 'Pricing and capital allocation in catastrophe insurance', Journal of Financial Economics 65(2): $283-305$.

\section{About the Author}

Christian Kraus is a Doctoral candidate and Research Assistant at the Institute of Insurance Science, University of Ulm, Germany. He studied mathematical economics at the University of Ulm, majoring in actuarial sciences. 